\title{
Communication
}

\section{Application of Hydrogen Peroxide to Improve the Microbiological Stability of Food Ice Produced in Industrial Facilities}

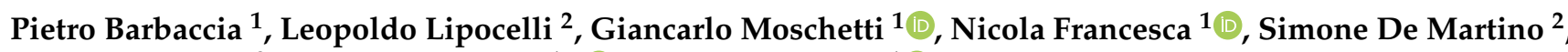 \\ Vincenzo Arrigo ${ }^{3}$, Raimondo Gaglio ${ }^{1, *(\mathbb{D})}$ and Luca Settanni ${ }^{1}$ (D) \\ 1 Dipartimento Scienze Agrarie, Alimentari e Forestali, Ed. 5, Università degli Studi di Palermo, \\ Viale delle Scienze, 90128 Palermo, Italy; pietro.barbaccia@unipa.it (P.B.); \\ giancarlo.moschetti@unipa.it (G.M.); nicola.francesca@unipa.it (N.F.); luca.settanni@unipa.it (L.S.) \\ 2 Ice Cube Impianti S.R.L., Contrada Canne Masche, 90018 Termini Imerese, Italy; \\ leopoldo.lipocelli@ice3.it (L.L.); simone.demartino@ice3.it (S.D.M.) \\ 3 Ambiente S.N.C. Dei Dott.ri V. Arrigo e V. Bellavia, Via Castellana, 2, 90018 Termini Imerese, Italy; \\ ambientesnc@yahoo.it \\ * Correspondence: raimondo.gaglio@unipa.it
}

check for updates

Citation: Barbaccia, P.; Lipocelli, L.; Moschetti, G.; Francesca, N.; De Martino, S.; Arrigo, V.; Gaglio, R.; Settanni, L. Application of Hydrogen Peroxide to Improve the Microbiological Stability of Food Ice Produced in Industrial Facilities. Appl. Sci. 2022, 12, 210. https:// doi.org/10.3390/app12010210

Academic Editors: Teresa Cirillo and Francesco Esposito

Received: 8 December 2021

Accepted: 24 December 2021

Published: 26 December 2021

Publisher's Note: MDPI stays neutral with regard to jurisdictional claims in published maps and institutional affiliations.

Copyright: (c) 2021 by the authors Licensee MDPI, Basel, Switzerland. This article is an open access article distributed under the terms and conditions of the Creative Commons Attribution (CC BY) license (https:// creativecommons.org/licenses/by/ $4.0 /)$.

\begin{abstract}
This work was aimed to produce an "active" food ice to preserve its microbiological safety over time. With this in mind, ice cubes were processed with the addition of $\mathrm{H}_{2} \mathrm{O}_{2}$ to water before freezing. Four food ice productions were performed at the industrial level: one control trial without the addition of $\mathrm{H}_{2} \mathrm{O}_{2}(0 \mathrm{OX})$ and three experimental trials obtained by adding 4, 8, and $12 \mathrm{mg} / \mathrm{L}$ of $\mathrm{H}_{2} \mathrm{O}_{2}(4 \mathrm{OX}, 8 \mathrm{OX}$, and 12OX), respectively. After production, all food ice trials were artificially contaminated with $10^{2} \mathrm{CFU} / 100 \mathrm{~mL}$ of water-borne pathogenic bacteria (Escherichia coli ATCC 25922, Enteroccus faecalis ATCC 29212, and Pseudomonas aeruginosa ATCC 27853) inoculated individually. Thawed ice samples were then subjected to microbiological analyses performed by the membrane filtration method and the results indicated that only trial 12OX was able to inactivate all bacteria strains. In conclusion, the addition of $12 \mathrm{mg} / \mathrm{L} \mathrm{H}_{2} \mathrm{O}_{2}$ represents an optimal cost-effective strategy to preserve the microbiological stability of food ice even when it is improperly handled after production.
\end{abstract}

Keywords: food ice production; hydrogen peroxide; hygiene; microbiological safety; water-borne bacteria

\section{Introduction}

In order to prevent waterborne diseases, the microbiological characteristics of drinking water are of extreme importance [1]; human life is strictly dependent on the quality of drinking water [2]. For this reason, the application of disinfection methods is necessary to reduce the microbiological risks related to drinking water [3] and its transformation products. The product obtained directly from potable water through the application of the freezing process is referred to as "food grade ice" or most commonly "food ice" [4]; this product is generally available for consumption in the form of cubes [5]. After melting, food ice becomes potable water [6] and it has to satisfy the minimum requirements on the hygiene of foodstuffs [7].

Industrial food ice is produced worldwide using ice machines and is commercialized after packing in plastic bags. Often, the quality and safety of packaged food ice does not meet the hygienic standards requested for drinking water [8] and this is imputable to improper handling during production [9], post-production contamination by the transformation environment [4], and to the packaging [10]. As a result, several microorganisms can be found in food ice, mainly intestinal bacteria [5,11,12], but also unicellular and filamentous fungi [13]. This is due to the capacity of the water microorganisms to survive the freezing process [14]. Bacteria reorganize their membrane lipids to face temperature or osmotic stresses $[15,16]$. Proteins placed on cytoplasm membranes are involved in various 
signal transduction pathways and can modify gene expression, significantly increasing the fluidity of this structure [17-19].

In order to improve the microbiological hygiene of food ice, a wide range of methods might be used to reduce or eliminate the microbial contamination in water for human consumption, which include chemical, physical, and physicochemical methods. Among the chemical methods, water chlorination is considered as one of the most efficient tools against enteric bacteria. This method is characterized by its low cost of maintenance [20], but chlorination byproducts are toxic, mutagenic, and/or carcinogenic [21]. Regarding the other methods, ozonation generates less byproducts than chlorination, but it is more expansive than this. Hydrogen peroxide $\left(\mathrm{H}_{2} \mathrm{O}_{2}\right)$ is an optimal oxidizer; it is classified as a non-specific bactericide effective against a wide range of bacteria [22] thanks also to the oxidant chemicals such as superoxide ions $\left(\mathrm{O}_{2}{ }^{-}\right)$and hydroxyl radicals $(\mathrm{OH})$ that can originate [23]. $\mathrm{H}_{2} \mathrm{O}_{2}$ is characterized by a certain manipulation safety [24] and is widely applied to treat drinking water [25]; due to the low levels applied in the water industry, it generates low levels of disinfection byproducts [26]. European directives do not establish a concentration limit for $\mathrm{H}_{2} \mathrm{O}_{2}$ in drinking water, although the Italian version of the UNI EN 902 [27] states: "Chemicals used for treatment of water intended for human consumption-Hydrogen peroxide" provides a dosage up to $17 \mathrm{mg} / \mathrm{L}$. During industrial ice cube production, the pre-treatment of water from the primary source and UV disinfection of water in the tank constitute critical control points, but after production and drying, packaging and storage represent two critical points that need to be considered for food ice microbial safety [4]. Based on the above considerations, this work was aimed to apply $\mathrm{H}_{2} \mathrm{O}_{2}$ at different doses to preserve the hygienic characteristics of food ice over time, especially during administration to the final consumers.

\section{Materials and Methods}

\subsection{Food Ice Production}

Ice cube production was carried out at an industrial facility (Ice Cube Impianti S.R.L., Termini Imerese, Italy) using drinking water from natural spring water sources of the Madonie Mountains (north Sicily). Ice making was performed by modifying the classical flowsheet of "Food Ice" making [28] using hydrogen peroxide $\left(\mathrm{H}_{2} \mathrm{O}_{2}\right)(48 \%$ w/w) (Figure 1) purchased from OX-CTA (Compañia de tratamiento de aguas, S.L., Huesca, Spain).

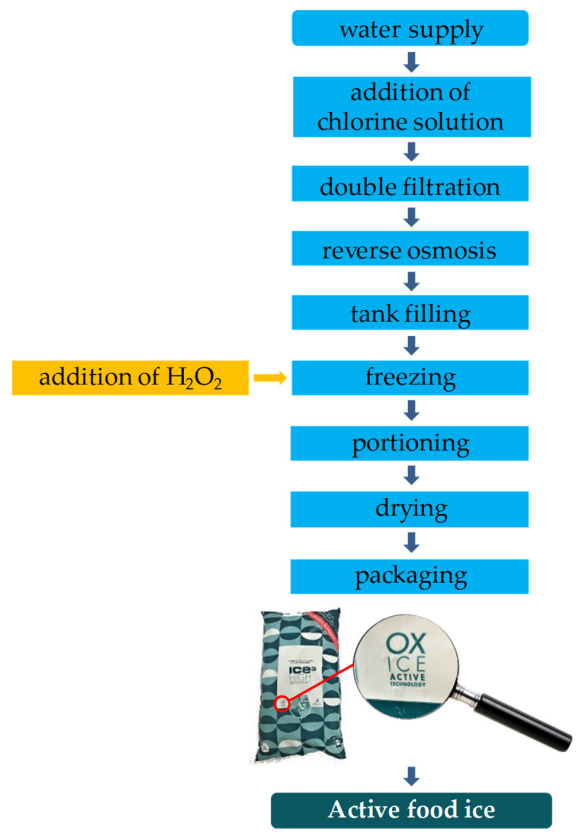

Figure 1. Flow diagrams of active food ice. 
The experimental plan included four different ice productions (OX-ICE technology): 0OX, control food ice production prepared without $\mathrm{H}_{2} \mathrm{O}_{2}$ addition; $4 \mathrm{OX}$, food ice production obtained adding $4 \mathrm{mg} / \mathrm{L}$ of $\mathrm{H}_{2} \mathrm{O}_{2} ; 8 \mathrm{OX}$, food ice production obtained adding $8 \mathrm{mg} / \mathrm{L}$ of $\mathrm{H}_{2} \mathrm{O}_{2}$; and 12OX, food ice production obtained adding $12 \mathrm{mg} / \mathrm{L}$ of $\mathrm{H}_{2} \mathrm{O}_{2}$. Each trial was obtained with $2000 \mathrm{~L}$ of water. Before production, the water was pre-treated with chlorine solution $(0.2 \mathrm{ppm})$ and then first transferred to quartz sand filter, and second, in a granular activated carbon filter to grab aqueous free chlorine and reduce potential health risks [29]. After filtration, in order to remove the divalent ions [30], water underwent a softening treatment followed by reverse osmosis. The water was then added with the given concentration of $\mathrm{H}_{2} \mathrm{O}_{2}$ for each trial through a pulsed-release system (Mitho S.R.L., Brescia, Italy) and finally transferred to the ice machine Vogt Tube-ice (Louisville, KY, USA) to produce ice cubes. At the end of the process, the resulting ice was portioned, dried, and packaged. Food ice production was carried out in duplicate in two consecutive weeks.

\subsection{Determination of the Concentrations of $\mathrm{H}_{2} \mathrm{O}_{2}$ in Food Ice}

Residual $\mathrm{H}_{2} \mathrm{O}_{2}$ in food ice was quantified by the laboratory Ambiente S.n.c. (Accredia Lab $n^{\circ}$ 0942) located at Termini Imerese (Palermo, Italy). Analyses were carried out following the methodology UNI EN 902 [7]. Briefly, $10 \mathrm{~mL}$ of thawed food ice was transferred into a flat-bottomed flask to which was added with $5 \mathrm{~mL}$ of $9 \mathrm{~N} \mathrm{H}_{2} \mathrm{SO}_{4}$ and $35 \mathrm{~mL} \mathrm{H}_{2} \mathrm{O}$ to bring the final volume to $50 \mathrm{~mL}$. The flask was subjected to manual agitation and the solution was added dropwise with $0.01 \mathrm{~N} \mathrm{KMnO}_{4}$ until the appearance of a pink color. The concentration of $\mathrm{H}_{2} \mathrm{O}_{2}$ was determined according to the following equation:

$$
\mathrm{c}=(\mathrm{S} * \mathrm{~V} * \mathrm{EW} * 1000) / \mathrm{Vs}
$$

where $\mathrm{c}$ is $\mathrm{H}_{2} \mathrm{O}_{2}$ concentration; $\mathrm{S}$ is the strength of $\mathrm{KMnO}_{4}$; $\mathrm{V}$ is the volume of $\mathrm{KMnO}_{4}$ used in titration; EW is the equivalent weight of $\mathrm{H}_{2} \mathrm{O}_{2}$; and $\mathrm{Vs}$ is the volume of food ice sample analyzed.

\subsection{Inactivation Assays}

In order to test the inhibitory properties of food ice containing 4,8 , and $12 \mathrm{mg} / \mathrm{L}$ of $\mathrm{H}_{2} \mathrm{O}_{2}$, three bacterial strains (Escherichia coli, Enteroccus faecalis, and Pseudomonas aeruginosa) belonging to the American Type Culture Collection (ATCC) were used as indicators (sensitive strains). The cultures were grown in Brain Heart Infusion (BHI) broth (Oxoid, Milan, Italy) at $37^{\circ} \mathrm{C}$ per $24 \mathrm{~h}$. All strains were prepared for the survival assay by centrifugation at $10,000 \times g$ for 5 min to separate cells from supernatants, washing, and re-suspension in Ringer's solution (Sigma-Aldrich, Milan, Italy). The cells of each test bacterium were inoculated at the final concentration of $10^{2}$ colony forming units (CFU)/100 mL, which represents the highest concentrations found in ice cubes produced at different extent $[4,5]$, in $500 \mathrm{~mL}$ volume sterile bottles (LP Italiana S.p.a, Milan, Italy) containing $300 \mathrm{~g}$ of food ice with and without $\mathrm{H}_{2} \mathrm{O}_{2}$. All contaminated systems were left at room temperature for $90 \mathrm{~min}$ until complete thawing and $100 \mathrm{~mL}$ was $0.2 \mu \mathrm{m}$ membrane filtered (GVS Filter Technology, Indianapolis, IN, USA). All membranes were transferred to agar media and incubated at the optimal growth conditions to allow colony development as follows: E. coli-Coliforms Chromogenic Medium (CHROMagar ${ }^{\mathrm{TM}}$ ) (Condolab, Madrid, Spain), incubated at $37^{\circ} \mathrm{C}$ for $24 \mathrm{~h}$, was used to enumerate E. coli ATCC25922; Pseudomonas-Agar Base (PAB) added with Cetrimide Fucidin Cephaloridine (CFC) supplement (Oxoid), incubated at $25^{\circ} \mathrm{C}$ for $48 \mathrm{~h}$ for P. aeruginosa ATCC27853; kanamycin aesculin azide (KAA) agar (Biotec, Grosseto, Italy), incubated at $37^{\circ} \mathrm{C}$ for $24 \mathrm{~h}$ for En. faecalis ATCC29212. Microbiological analyses were carried out in duplicate.

\subsection{Statistical Analysis}

Microbiological data were subjected to one-way variance analysis (ANOVA) using XLStat software version 7.5.2 for Excel (Addinsoft, New York, NY, USA). The Tukey's test was applied for pairwise comparison between count levels of each individual microorganism at 
different $\mathrm{H}_{2} \mathrm{O}_{2}$ concentrations. Statistical significance was attributed to $p$ values of $p<0.05$ and are marked with different letters.

\section{Results and Discussion}

In this study, the strains E. coli ATCC25922, En. faecalis ATCC29212, and P. aeruginosa ATCC27853 were used as indicator strains to test the efficacy of $\mathrm{H}_{2} \mathrm{O}_{2}$ to process ice. The species E. coli, En. faecalis, and P. aeruginosa, generally transmitted by ice [31], represent the main pathogens used for the evaluation of the mandatory and accessory parameters provided by the Italian Legislative Decree No. 31/2001 [32] for the implementation of directive 98/83/EC. The results of survival tests, expressed as CFU/100 mL of thawed ice, are reported in Figure 2.

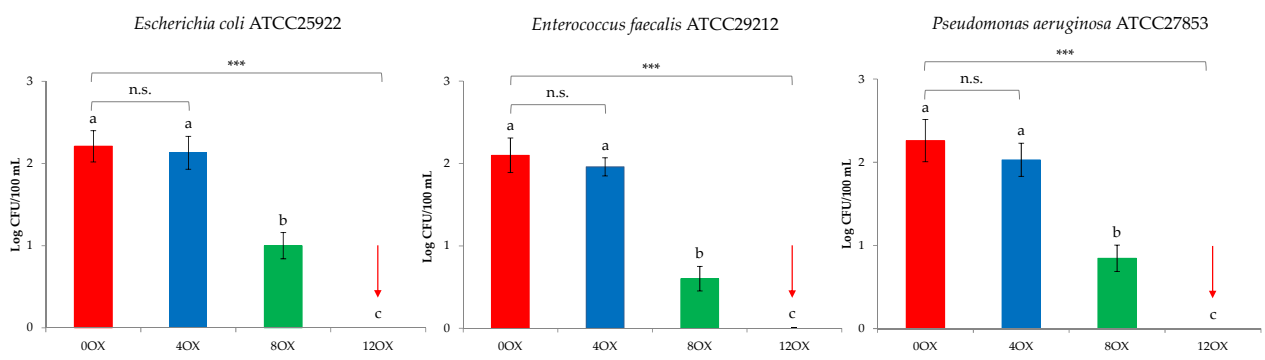

Figure 2. Counts of water-borne pathogenic bacteria in food ice activated with different concentrations of $\mathrm{H}_{2} \mathrm{O}_{2}$. $p$ value: ${ }^{* *} p<0.001$; n.s. - not significant. The letters $\mathrm{a}, \mathrm{b}$, and $\mathrm{c}$ on the histograms indicate difference between the samples analyzed according to Tukey's test.

After bacterial inoculation, the cell densities of control ice samples (0OX) were 2.21, 2.10, and 2.26 Log CFU/100 mL for E. coli ATCC25922, En. faecalis ATCC29212, and P. aeruginosa ATCC27853, respectively. In more detail, Figure 2 shows that the antibacterial activity of the food ice activated with different concentrations of $\mathrm{H}_{2} \mathrm{O}_{2}$ was comparable among the different strains tested. No significant differences $(p>0.05)$ were found among the levels of microbial count for the trials 0OX and 4OX between the same bacteria strains, showing that the presence of $4 \mathrm{mg} / \mathrm{L}$ of $\mathrm{H}_{2} \mathrm{O}_{2}$ in the food ice did not exert any disinfecting action. In contrast, the counts of the three bacteria decreased significantly $(p<0.001)$ with increasing $\mathrm{H}_{2} \mathrm{O}_{2}$ concentration. In particular, E. coli ATCC25922, En. faecalis ATCC29212, and P. aeruginosa ATCC27853 decreased consistently in the 8OX trial and were not detected in the $12 \mathrm{OX}$ samples, showing the bactericidal efficacy of $\mathrm{H}_{2} \mathrm{O}_{2}$ at the concentration of $12 \mathrm{mg} / \mathrm{L}$ against both Gram-positive (En. faecalis) and Gram-negative (E. coli and P. aeruginosa) bacteria commonly searched in water to establish its drinkability [33].

Ríos-Castillo et al. [34] demonstrated the effect of $\mathrm{H}_{2} \mathrm{O}_{2}$ at $0.5 \%$ in combination with other products (benzalkonium chloride, cationic polymer, ethoxylated fatty alcohol, and ethyl alcohol) used in food industries against E. coli, Staphylococcus aureus, Enterococcus hirae, and $P$. aeruginosa on stainless steel surfaces. However, the authors found differences in terms of bacterial sensitivity and evidenced a more pronounced effect of the mixtures used when the test organisms were En. hirae and P. aeruginosa. Lineback et al. [35] demonstrated that $\mathrm{H}_{2} \mathrm{O}_{2}$ at different concentrations were more than quaternary ammonium compounds effective against $S$. aureus and $P$. aeruginosa biofilms. Furthermore, Alfa et al. [36] demonstrated that a concentration of $0.5 \% \mathrm{H}_{2} \mathrm{O}_{2}$ represented a highly efficient antimicrobial strategy to disinfect medical devices. Regarding food applications of $\mathrm{H}_{2} \mathrm{O}_{2}$, Arefin et al. [37] used several concentrations of this compound for raw cow's milk preservation, demonstrating that $0.14 \%$ of $\mathrm{H}_{2} \mathrm{O}_{2}$ was suitable to extend the milk shelf-life where milk cooling facilities were not available. Hence, $\mathrm{H}_{2} \mathrm{O}_{2}$ seems to be a proper compound to contain intestinal bacteria that can be found in water/food ice [5] at low cost. 


\section{Conclusions}

This study provides, for the first time, an extended analysis on the survival of the main pathogens responsible for water-borne diseases in humans in food ice produced at industrial level with different concentrations of $\mathrm{H}_{2} \mathrm{O}_{2}$. The results of this study showed that the major bacterial species that compromise the drinkability of water such as E. coli, En. faecalis, and P. aeruginosa were inhibited by $12 \mathrm{mg} / \mathrm{L} \mathrm{of} \mathrm{H}_{2} \mathrm{O}_{2}$ added to food ice during production. These results represent a final solution to preserve the microbiological stability of food ice, even when it is improperly handled after production. As a matter of fact, unlike all other food products, food ice is exposed to a high risk of unintentional contaminations, especially in the HORECA (hotel, restaurants and catering) channel where this product is commonly used. Thus, OX-ICE represents a useful technology to process food ice. However, further studies are necessary to evaluate oxidizability of water from thawed ice added with $\mathrm{H}_{2} \mathrm{O}_{2}$.

Author Contributions: Conceptualization, L.L., S.D.M., R.G. and L.S.; Methodology, G.M. and R.G.; Software, N.F. and R.G.; Validation, R.G. and L.S.; Formal analysis, R.G. and L.S.; Investigation, P.B. and V.A.; Data curation, R.G.; Writing—original draft preparation, R.G.; Writing-review and editing, R.G. and L.S. All authors have read and agreed to the published version of the manuscript.

Funding: This research received no external funding.

Institutional Review Board Statement: Not applicable.

Informed Consent Statement: Not applicable.

Data Availability Statement: All data included in this study are available upon request by contacting the corresponding author.

Acknowledgments: The authors are grateful to Ice Cube Impianti S.R.L. (Termini Imerese, Italy) for the materials used for the experiments.

Conflicts of Interest: The authors declare no conflict of interest.

\section{References}

1. Barrell, R.A.; Hunter, P.R.; Nichols, G. Microbiological standards for water and their relationship to health risk. Commun. Dis. Public Health 2000, 3, 8-13. [PubMed]

2. $\quad$ Lautenschlager, K.; Hwang, C.; Liu, W.; Boon, N.; Koester, O.; Vrouwenvelder, H.; Egli, T.; Hammes, F. A microbiology-based multi-parametric approach towards assessing biological stability in drinking water distribution networks. Water Res. 2013, 47, 3015-3025. [CrossRef] [PubMed]

3. Zeng, F.; Cao, S.; Jin, W.; Zhou, X.; Ding, W.; Tu, R.; Han, F.S.; Wang, C.; Jang, Q.; Huang, H.; et al. Inactivation of chlorine-resistant bacterial spores in drinking water using UV irradiation, UV/Hydrogen peroxide and UV/Peroxymonosulfate: Efficiency and mechanism. J. Clean. Prod. 2020, 243, 118666. [CrossRef]

4. Settanni, L.; Gaglio, R.; Stucchi, C.; De Martino, S.; Francesca, N.; Moschetti, G. Presence of pathogenic bacteria in ice cubes and evaluation of their survival in different systems. Ann. Microbiol. 2017, 67, 827-835. [CrossRef]

5. Gaglio, R.; Francesca, N.; Di Gerlando, R.; Mahony, J.; De Martino, S.; Stucchi, C.; Moschetti, G.; Settanni, L. Enteric bacteria of food ice and their survival in alcoholic beverages and soft drinks. Food Microbiol. 2017, 67, 17-22. [CrossRef]

6. Falcao, J.P.; Dias, A.M.G.; Correa, E.F.; Falcao, D.P. Microbiological quality of ice used to refrigerate foods. Food Microbiol. 2002, 19, 269-276. [CrossRef]

7. Regulation (EC) No 1882/2003 of the European Parliament and of the Council of 29 September 2003 Adapting to Council Decision 1999/468/EC the Provisions Relating to Committees Which Assist the Commission in the Exercise of Its Implementing Powers Laid down in Instruments Subject to the Procedure Referred to in Article 251 of the EC Treaty. Available online: https:/ / eur-lex.europa.eu/legal-content/IT/TXT/PDF/?uri=CELEX:32003R1882\&from=EN (accessed on 25 November 2020).

8. Lee, K.H.; Ab Samad, L.S.; Lwin, P.M.; Riedel, S.F.; Magin, A.; Bashir, M.; Vaishampayan, P.A.; Lin, W.J. On the Rocks: Microbiological Quality and Microbial Diversity of Packaged Ice in Southern California. J. Food Prot. 2017, 80, 1041-1049. [CrossRef]

9. Noor Izani, N.J.; Zulaikha, A.R.; Mohamad Noor, M.R.; Amri, M.A.; Mahat, N.A. Contamination of faecal coliforms in ice cubes sampled from food outlets in Kubang Kerian, Kelantan. Trop. Biomed. 2012, 29, 71-76.

10. Chavasit, V.; Sirilaksanamanon, K.; Phithaksantayothin, P.; Norapoompipat, Y.; Parinyasiri, T. Measures for controlling safety of crushed ice and tube ice in developing country. Food Control 2011, 22, 118-123. [CrossRef] 
11. Lateef, A.; Oloke, J.K.; Kana, E.B.G.; Pacheco, E. The microbiological quality of ice used to cool drinks and foods in Ogbomoso Metropolis, Southwest, Nigeria. Int. J. Food Saf. 2006, 8, 39-43.

12. Ukwo, S.P.; Ndaeyo, N.U.; Udoh, E.J. Microbiological quality and safety evaluation of fresh juices and edible ice sold in Uyo Metropolis, South-South, Nigeria. Int. J. Food Saf. 2011, 13, 374-378.

13. Francesca, N.; Gaglio, R.; Stucchi, C.; De Martino, S.; Moschetti, G.; Settanni, L. Yeasts and moulds contaminants of food ice cubes and their survival in different drinks. J. Appl. Microbiol. 2018, 124, 188-196. [CrossRef] [PubMed]

14. Dickens, D.L.; DuPont, H.L.; Johnson, P.C. Survival of bacterial enteropathogens in the ice of popular drinks. JAMA 1985, 253, 3141-3143. [CrossRef] [PubMed]

15. Yamazaki, M.; Ohnishi, S.; Ito, T. Osmoelastic coupling in biological structures: Decrease in membrane fluidity and osmophobic association of phospholipid vesicles in response to osmotic stress. Biochemistry 1989, 28, 3710-3715. [CrossRef]

16. Los, D.A.; Murata, N. Membrane fluidity and its roles in the perception of environmental signals. Biochim. Biophys. Acta 2004, 1666, 142-157. [CrossRef]

17. Kamada, Y.; Jung, U.S.; Piotrowski, J.; Levin, D.E. The protein kinase C-activated MAP kinase pathway of Saccharomyces cerevisiae mediates a nove1 aspect of the heat shock response. Genes Dev. 1995, 9, 1559-1571. [CrossRef]

18. de Jonge, H.W.; Dekkers, D.H.; Bastiaanse, E.M.; Bezstarosti, K.; van der Laarse, A.; Lamers, J.M. Eicosapentaenoic acid incorporation in membrane phospholipids modulates receptor-mediated phospholipase $\mathrm{C}$ and membrane fluidity in rat ventricular myocytes in culture. J. Mol. Cell. Cardiol. 1996, 28, 1097-1108. [CrossRef]

19. Los, D.A.; Murata, N. Regulation of enzymatic activity and gene expression by membrane fluidity. Sci. Signal Transduct. Knowl. Environ. 2000, 62, 1. [CrossRef]

20. Wagner, M.; Brumelis, D.; Gehr, R. Disinfection of wastewater by hydrogen peroxide or peracetic acid: Development of procedures for measurement of residual disinfectant and application to a physicochemically treated municipal effluent. Water Environ. Res. 2002, 74, 33-50. [CrossRef]

21. Veschetti, E.; Cutilli, D.; Bonadonna, L.; Briancesco, R.; Martini, C.; Cecchini, G.; Anastasi, P.; Ottaviani, M. Pilot-plant comparative study of peracetic acid and sodium hypochlorite wastewater disinfection. Water Res. 2003, 37, 78-94. [CrossRef]

22. Finnegan, M.; Linley, E.; Denyer, S.P.; McDonnell, G.; Simons, C.; Maillard, J.Y. Mode of action of hydrogen peroxide and other oxidizing agents: Differences between liquid and gas forms. J. Antimicrob. Chemother. 2010, 65, 2108-2115. [CrossRef] [PubMed]

23. Watts, R.J.; Teel, A.L. Hydroxyl radical and non-hydroxyl radical pathways for trichloroethylene and perchloroethylene degradation in catalyzed $\mathrm{H}_{2} \mathrm{O}_{2}$ propagation systems. Water Res. 2019, 159, 46-54. [CrossRef] [PubMed]

24. Labas, M.D.; Zalazar, C.S.; Brandi, R.J.; Cassano, A.E. Reaction kinetics of bacteria disinfection employing hydrogen peroxide. Biochem. Eng. J. 2008, 38, 78-87. [CrossRef]

25. Li, W.; Bonakdarpour, A.; Gyenge, E.; Wilkinson, D.P. Production of Hydrogen Peroxide for Drinking Water Treatment in a Proton Exchange Membrane Electrolyzer at Near-Neutral pH. J. Electrochem. Soc. 2020, 167, 044502. [CrossRef]

26. Pedahzur, R.; Lev, O.; Fattal, B.; Shuval, H.I. The interaction of silver ions and hydrogen peroxide in the inactivation of E. coli: A preliminary evaluation of a new long acting residual drinking water disinfectant. Water Sci. Technol. 1995, 31, 123-129. [CrossRef]

27. Italian Standards Institution. Chemicals Used for Treatment of Water Intended for Human Consumption. In Hydrogen Peroxide; Italian Standards Institution: Milan, Italy, 2016.

28. Istituto Nazionale Ghiaccio Alimentare. Manuale di Corretta Prassi Operativa per la Produzione di Ghiaccio Alimentare. 2015. Available online: https://www.salute.gov.it/imgs/C_17_pagineAree_1187_listaFile_itemName_0_file.pdf (accessed on 25 November 2021).

29. Meng, F.; Li, G.; Zhang, B.; Guo, J. Chemical kinetics and particle size effects of activated carbon for free chlorine removal from drinking water. Water Pract. Technol. 2019, 14, 19-26. [CrossRef]

30. Seo, S.J.; Jeon, H.; Lee, J.K.; Kim, G.Y.; Park, D.; Nojima, H.; Lee, J.; Moon, S.H. Investigation on removal of hardness ions by capacitive deionization (CDI) for water softening applications. Water Res. 2010, 44, 2267-2275. [CrossRef]

31. Caggiano, G.; Marcotrigiano, V.; Trerotoli, P.; Diella, G.; Rutigliano, S.; Apollonio, F.; Marzella, A.; Triggiano, F.; Gramegna, M.; Lagravinese, D.; et al. Food hygiene surveillance in Italy: Is food ice a public health risk? Int. J. Environ. Res. 2020, 17, 2408.

32. Decreto Legislativo 2 Febbraio 2001, n. 31. "Attuazione della Direttiva 98/83/CE Relativa alla Qualità delle Acque Destinate al Consumo Umano". GU n. 52 del 3 Marzo 2001-Supplemento Ordinario n. 41. Available online: https://www.camera.it/parlam/ leggi/deleghe/01031dl.htm (accessed on 24 November 2021).

33. Moschetti, G.; Settanni, L. Acqua e bevande non alcoliche. In Microbiologia dei Prodotti Alimentari; Farris, A., Gobbetti, M., Neviani, E., Vincenzini, M., Eds.; Casa Editrice Ambrosiana: Milan, Italy, 2012; pp. 141-152.

34. Ríos-Castillo, A.G.; González-Rivas, F.; Rodríguez-Jerez, J.J. Bactericidal efficacy of hydrogen peroxide-based disinfectants against gram-positive and gram-negative bacteria on stainless steel surfaces. J. Food Sci. 2017, 82, 2351-2356. [CrossRef]

35. Lineback, C.B.; Nkemngong, C.A.; Wu, S.T.; Li, X.; Teska, P.J.; Oliver, H.F. Hydrogen peroxide and sodium hypochlorite disinfectants are more effective against Staphylococcus aureus and Pseudomonas aeruginosa biofilms than quaternary ammonium compounds. Antimicrob. Resist. Infect. Control 2018, 7, 1-7. [CrossRef] 
36. Alfa, M.J.; Jackson, M.A. New hydrogen peroxide-based medical-device detergent with germicidal properties: Comparison with enzymatic cleaners. Am. J. Infect. Control 2001, 29, 168. [CrossRef] [PubMed]

37. Arefin, S.; Sarker, M.A.H.; Islam, M.A.; Harun-ur-Rashid, M.; Islam, M.N. Use of Hydrogen Peroxide $\left(\mathrm{H}_{2} \mathrm{O}_{2}\right)$ in raw cow's milk preservation. J. Adv. Vet. Anim. Res. 2017, 4, 371-377. [CrossRef] 